\section{UJ APLIKASI BERBAGAI TINGKAT DOSIS PUPUK ZA TERHADAP PRODUKTIVITAS DAN MUTU JAGUNG}

\author{
M. Aqil ${ }^{2}$ \\ Roy Efendi 3
}

${ }^{*}$ Fahdiana Tabri ${ }^{1}$

1,2,3Balai Penelitian Tanaman Serealia, Jl. DR.Ratulangi No,. 274 Maros 90514

*E-mail : fahdiana_tabri@yahoo.co.id

Abstrak. Penelitian ini bertujuan untuk melihat pengaruh pemberian dan dosis optimal pupuk ZA terhadap produktivitas dan mutu jagung. Hasil percobaan menunjukkan bahwa perlakuan tanpa urea, pada perlakuan dosis pupuk NPK 300/kg + ZA $100 \mathrm{~kg} / \mathrm{ha}$ akan menurunkan hasil produksi dari 10,8 ton/ha menjadi 9,1 ton/ha, dan B-C Rasio 2,34 menjadi 2,08. Selanjutnya perlakuan tanpa urea (NPK + Urea) mempunyai produksi tertinggi pada pemberian pupuk NPK $300 \mathrm{~kg} / \mathrm{ha}+$ ZA $200 \mathrm{~kg} / \mathrm{ha}$ dengan tingkat keuntungan Rp. 20.435.000,- dan B-C Rasio 2,21. Selanjutnya penambahan takaran pupuk ZA malah akan menurunkan hasil produksi serta B-C Rasionya.

Kata Kunci : Pupuk ZA, produktivitas, mutu, jagung.

\section{INDONESIAN JOURNAL OF FUNDAMENTAL SCIENCES (IJFS)}

\section{E-ISSN: 2621-6728 \\ P-ISSN: 2621-671X}

Submitted: August 22 ${ }^{\text {th }}, 2017$

Accepted : December, $1^{\text {st }}, 2017$

Abstract. This study aims to see the effect of optimal dosage of ZA fertilizer on maize productivity and quality. The results showed that the treatment without urea, in the treatment of NPK $300 / \mathrm{kg}+$ ZA 100 $\mathrm{kg} \mathrm{/} \mathrm{ha} \mathrm{fertilizer} \mathrm{dosage} \mathrm{will}$ decrease the yield from 10.8 tons / ha to 9.1 tons / ha, and BC Ratio 2.34 to 2, 08. Further treatment without urea (NPK + Urea) has the highest production of NPK fertilizer $300 \mathrm{~kg} /$ ha + ZA $200 \mathrm{~kg} /$ ha with profit rate Rp. 20.435.000, - and B-C Ratio 2.21. Furthermore the addition of ZA fertilizer doses will actually reduce the production and B-C Ratio 


\section{PENDAHULUAN}

Produksi jagung periode 2011-2014, surplus neraca pangan jagung Indonesia cukup besar dalam bentuk pipilan kering mencapai 19,03 juta ton dengan luas lahan sebesar 3,8 juta hektar pada tahun 2014 mengalami kenaikan sebesar 2,81\% dibandingkan pada tahun 2013 (18,51 juta ton). Kenaikan produksi terjadi, baik di Pulau Jawa maupun di luar Pulau Jawa pada periode sekitar Mei-Agustus dan September-Desember 2014 karena adanya kenaikan produktivitas sekitar 2,87\% per tahun ( BPS 2015). Hasil ini masih dapat ditingkatkan dengan pemberian pupuk yang tepat, baik dosis, waktu maupun jenis pupuk yang diberikan. Berdasarkan data pemakaian pupuk ZA, penyerapan pupuk ZA dari tahun 2010 s/d 2012 cenderung mengalami peningkatan. Peningkatan penyerapan pupuk ZA tersebar diseluruh propinsi, peningkatan tersebut diduga disebabkan oleh perpindahan pola pemupukan dari pupuk Urea menjadi pupuk ZA, dimana pada $100 \mathrm{~kg}$ pupuk ZA terdapat $20,8 \mathrm{~kg}$ unsur nitrogen (Jones et al., 1991).

Komoditas sektor pangan yang diduga menyerap pupuk ZA dalam jumlah tinggi adalah tanaman padi dan jagung, dalam meningkatkan produktivitas tanaman jagung, peranan pupuk sangat penting terutama unsur hara makro N,P dan K, selain membutuhkan unsur hara makro NPK, juga membutuhkan unsur hara Sulfur (S) sebesar 12,6 kg S ha-1 dan $21 \mathrm{~kg} \mathrm{~S} \mathrm{ha}^{-1}$. Kebutuhan tersebut dapat dipenuhi dengan dosis ZA antara 50- $60 \mathrm{~kg} \mathrm{ha}^{-1}$. Melalui program pemupukan berimbang, diharapkan produktivitas tanaman dan tanah dapat dioptimalkan, pendapatan petani meningkat, pemupukan menjadi lebih efisien dan menguntungkan, serta menghindari pencemaran lingkungan (FAO, 2012). Pupuk ZA memberikan unsur $\mathrm{N}$ yang mudah tersedia dalam waktu yang cukup cepat bagi tanaman. Unsur lain yang terkandung dalam pupuk ZA adalah sulfur (S) yang dipergunakan dalam pembentukan umbi. Sulfur merupakan penyusun asam-asam amino esensial yang terlibat dalam pembentukan klorofil, dan dibutuhkan dalam sintesis protein dan struktur tanaman (Mengel and Kirby 1987). Sulfur juga sebagai penyusun koenzim A dan hormon biotin dan thiamin yang dibutuhkan dalam metabolisme karbohidrat (Dobermann and Fairhurst 2000). Menurut Swandi (1999) dan Fageria (2009),bahwa nitrogen merupakan salah satu unsur makro yang dibutuhkan dalam jumlah yang cukup banyak untuk pertumbuhan tanaman.

Berdasarkan hasil survei Purnomo et.al (1989) dan Fagi et.al (1994) menunjukkan bahwa tanah-tanah sawah yang berada di Pulau Jawa dan Madura mengalami kekurangan Sulfur seluas 2.052 .650 ha atau 58,48 \% dari total luas sawah yang disurvei sebesar 3.509.923 ha. Sehingga kurangnya Sulfur dalam tanah akan menjadikan tanaman padi responsif terhadap pemupukan ZA yang mengandung Sulfur. Penelitian ini bertujuan untuk mempelajari pengaruh pemberian dan dosis optimal pupuk ZA terhadap produktivitas dan kualitas tanaman jagung. 


\section{METODE PENELITIAN}

Penelitian dilaksanakan di kebun percobaan Balitsereal Maros, pada bulan Agustus hingga Desember 2014 , menggunakan Rancangan Acak kelompok (RAK) dengan 8 Perlakuan dan 3 ulangan yang dicobakan terdiri dari berbagai tingkat dosis pupuk ZA sebagai berikut:

1. Tanpa Pupuk

2. Pupuk Rekomendasi (NPK $300 \mathrm{~kg} / \mathrm{ha}$ dan urea $300 \mathrm{~kg} / \mathrm{ha}$ )

3. Pupuk NPK $300 \mathrm{~kg} / \mathrm{ha}+$ Urea $200 \mathrm{~kg} / \mathrm{ha}+\mathrm{ZA} 100 \mathrm{~kg} / \mathrm{ha}$

4. Pupuk NPK $300 \mathrm{~kg} / \mathrm{ha}+\mathrm{ZA} 50 \mathrm{~kg} / \mathrm{ha}$

5. Pupuk NPK $300 \mathrm{~kg} / \mathrm{ha}+Z A 100 \mathrm{~kg} / \mathrm{ha}$

6. Pupuk NPK $300 \mathrm{~kg} / \mathrm{ha}+Z A 150 \mathrm{~kg} / \mathrm{ha}$

7. Pupuk NPK $300 \mathrm{~kg} / \mathrm{ha}+\mathrm{ZA} 200 \mathrm{~kg} / \mathrm{ha}$

8. Pupuk NPK $300 \mathrm{~kg} / \mathrm{ha}+\mathrm{ZA} 250 \mathrm{~kg} / \mathrm{ha}$

9. Pupuk NPK $300 \mathrm{~kg} / \mathrm{ha}+\mathrm{ZA} 300 \mathrm{~kg} / \mathrm{ha}$

Benih jagung yang digunakan adalah jenis hibrida varietas Pioner-21, ditanam sebanyak 2 biji perlubang dengan jarak $75 \mathrm{~cm} \times 20 \mathrm{~cm}$.Ukuran petak tiap perlakuan $6 \mathrm{~m} \times 4 \mathrm{~m}$. Pada umur 1 minggu (sebelum pemupukan) dilakukan penjarangan dengan cara menggunting pada pangkal bantang sehingga tinggal 1 tanam/rumpun. Pengendalian hama dan Penyakit tergantung serangan yang ada dilapangan. Pemupukan majemuk NPK, urea dan ZA pada setiap plot dilakukan dengan takaran sesuai perlakuan yang diujikan. Pemupukan I (pertama) dilakukan pada saat tanaman berumur 10 - 15 hst ( hari sesudah tanam) dengan takaran 1/2 dari takaran perlakuan sedangkan sisanya diberikan pada pemupukan II (kedua) yang dilakukan pada saat tanaman berumur 30-35 hst. Pemberian dilakukan dengan cara tugal disamping barisan tanaman. Data pengamatan Vegetatif antara lain : Tinggi tanaman (cm), diameter batang, Jumlah daun (helai), Klorofil daun 35 hst, dan Bagan Warna Daun untuk melihat intensitas kehijauan pada daun. sedang untuk parameter hasil meliputi : Jumlah baris pertongkol, Jumlah biji perbaris, Bobot 1000 biji (gram), Bobot tongkol (kg), Panjang tongkol (cm), Lingkar tongkol (cm), Bobot tongkol/ha (kg), Analisis tanah sebelum dan sesudah percobaan dan Analisis Usahatani.

\section{HASIL DAN PEMBAHASAN}

\section{Kandungan Hara dalam Tanah}

Hasil analisis tanah pada lahan percobaan sebelum dilakukan penanaman dan pemupukan menunjukkan bahwa tekstur tanah sedang dengan 50\% tanah terdiri dari pasir, 37\% dari debu dan hanya 13\% dari liat. pH tanah tergolong agak masam. Kandunga $\mathrm{P}$ tanah tergolong tingii dengan nilai 26,48 ppm, kapasitas tukar kation $\mathrm{K}$ tergolong rendah dengan nilai $0,17 \mathrm{me} / 100 \mathrm{~g}$, dan kandungan bahan organik sangat rendah yaitu $0,76 \%$ yang menunjukkan kandungan total $\mathrm{N}$ tanah sangat 
rendah yaitu 0,06\%. Kapasitas tukar kation $\mathrm{Na}$ dan $\mathrm{Mg}$ tergolong sangat tinggi masing-masing 0,11 dan 16,48 me/10og.

Tabel 1. Hasil analisis sifat fisik dan kimia tanah sebelum tanam

\begin{tabular}{|c|c|}
\hline Macam penetapan & Nilai penetapan \\
\hline Tekstur & Lempung \\
\hline Liat (\%) & 13 \\
\hline Debu (\%) & 37 \\
\hline Pasir(\%) & 50 \\
\hline $\mathrm{pH}(1: 2,5)$ & 5,98 \\
\hline $\mathrm{KCl}(1: 2,5)$ & 4,65 \\
\hline C, Organik & 0,76 \\
\hline Nitrogen Total (\%) & 0,06 \\
\hline $\mathrm{C} / \mathrm{N}$ & 12,67 \\
\hline P Bray 1(ppm) & 26,48 \\
\hline \multicolumn{2}{|l|}{ Kation dapat ditukar } \\
\hline K & 0,17 \\
\hline $\mathrm{Ca}$ & 3,46 \\
\hline Mg & 16,48 \\
\hline $\mathrm{Na}$ & 0,11 \\
\hline $\mathrm{SO}_{4}$ & 2,19 \\
\hline Al-dd(me/100 g) & 0 \\
\hline $\mathrm{H}+(\mathrm{me} / \mathrm{100} \mathrm{g})$ & 0,12 \\
\hline KTK (me/10o g) & 8,93 \\
\hline Kejenuhan Basa (\%) & 226,54 \\
\hline
\end{tabular}

Pemberian pupuk urea pada perlakuan pemupukan NPK $300 \mathrm{~kg} / \mathrm{ha}$ dan urea $300 \mathrm{~kg} / \mathrm{ha}$ (B) dan NPK $300 \mathrm{~kg} / \mathrm{ha}$ dan urea $200 \mathrm{~kg} / \mathrm{ha}$ dan ZA $100 \mathrm{~kg} / \mathrm{ha}$ (C) berdampak pada menurunkan pH tanah yaitu menjadi 5,53 - 5,59 (Tabel 2) dimana $\mathrm{pH}$ awal tanah (Tabel 1) atau tanah tidak dipupuk adalah 5,98-6,06. Pemberian pupuk ZA dengan takaran $50-300 \mathrm{~kg} / \mathrm{ha}$ (perlakuan C - I) masih dapat mempertahankan pH tanah awal yaitu 5,93 - 6,13. Pengaruh ZA terhadap ketersedian hara $\mathrm{K}$ menunjukan lebih baik daripada pupuk Urea. Kadar $\mathrm{K}$ dalam tanaman yang dipupuk ZA dapat meningkatkan ketersedian $\mathrm{K}$ sebesar 28,1-46,8\% (Tabel 2), hal tersebut sejalan dengan hasil penelitian Ispandi dan Munip (2004) yang menyatakan bahwa pemupukan ZA meningkatkan serapan dan ketersedian $P$ dan K. Adanya gugusan sulfat dalam ZA dapat menghambat terfiksasinya hara $P$ oleh Ca menjadi kalsium fosfat karena reaksi antara ion Ca dan gugusan sulfat lebih cepat dari pada antara ion Ca dengan ion fosfat. Antara ion Ca dengan ion sulfat akan terbentuk kalsium sulfat (Feagley and Hossner, 1978). Dengan terfiksasinya ion 
Ca oleh ion sulfat akan memberi peluang lebih lama bagi tanaman untuk menyerap ion kalium dari dalam tanah termasuk yang berasal dari pupuk $\mathrm{K}$.

Penambahan pupuk ZA sampai $300 \mathrm{~kg} /$ ha tidak merubah pH tanah secara nyata, hal ini dimunginkan curah hujan yang cukup tinggi pada bulan Desember-Januari 2015. Di dalam tanah, sifat asam dari ZA dapat meningkatkan ketersediaan hara $\mathrm{P}$ di tanah yang bereaksi alkalis akibat menurunnya $\mathrm{pH}$ tanah di daerah yang tersentuh pupuk ZA (Miller et al., 1990).

Tabel 2. Kandungan hara tanah setelah panen

\begin{tabular}{|c|c|c|c|c|c|c|c|c|c|}
\hline Macam penetapan & A & $B$ & $C$ & $\mathrm{D}$ & $E$ & $\mathrm{~F}$ & $G$ & $\mathrm{H}$ & $\mathrm{I}$ \\
\hline $\mathrm{pH}(1: 2,5)$ & 6,06 & 5,53 & 5,59 & 6,13 & 6,11 & 5,97 & 6,10 & 5,96 & 5,93 \\
\hline $\mathrm{KCl}(1: 2,5)$ & 4,98 & 4,48 & 4,97 & 5,02 & 4,98 & 4,74 & 5,08 & 4,84 & 4,79 \\
\hline C, Organik & 0,31 & 0,48 & 0,34 & 0,42 & 0,35 & 0,47 & 0,40 & 0,32 & 0,45 \\
\hline Nitrogen Total (\%) & 0,03 & 0,03 & 0,03 & 0,03 & 0,04 & 0,04 & 0,02 & 0,02 & 0,03 \\
\hline $\mathrm{C} / \mathrm{N}$ & 8,75 & 16,00 & 11,33 & 14 & 10,33 & 11,75 & 20,00 & 16,00 & 15,00 \\
\hline P Bray 1(ppm) & 17,53 & 20,44 & 21,27 & 20,04 & 20,58 & 22,54 & 21,01 & 21,81 & 25,66 \\
\hline \multicolumn{10}{|l|}{ Kation dapat ditukar } \\
\hline K & 0,17 & 0,32 & 0,47 & 0,30 & 0,42 & 0,44 & 0,47 & 0,41 & 0,42 \\
\hline $\mathrm{Ca}$ & 7,87 & 7,51 & 7,92 & 7,89 & 8,93 & 9,60 & 8,20 & 8,13 & 8,67 \\
\hline$M g$ & 5,59 & 3,91 & 5,21 & 4,98 & 5,06 & 4,38 & 2,06 & 2,29 & 4,02 \\
\hline $\mathrm{Na}$ & 0,08 & 0,31 & 0,21 & 0,72 & 0,17 & 0,17 & 0,17 & 0,21 & 0,13 \\
\hline $\mathrm{SO}_{4}$ & 3,83 & 3,18 & 4,95 & 2,48 & 2,78 & 2,69 & 3,59 & 1,86 & 1,85 \\
\hline $\mathrm{H}+(\mathrm{me} / 100 \mathrm{~g})$ & 0,08 & 0,19 & 0,15 & 0,11 & 0,12 & 0,13 & 0,10 & 0,13 & 0,13 \\
\hline KTK (me/10o g) & 11,06 & 9,41 & 4,89 & 11,60 & 15,39 & 8,87 & 13,99 & 8,86 & 10,53 \\
\hline
\end{tabular}

Keterangan:
A. Tanpa Pupuk
F. Pupuk NPK $300 \mathrm{~kg} / \mathrm{ha}+Z A 150 \mathrm{~kg} / \mathrm{ha}$
B. Pupuk Rekomendasi (NPK $300 \mathrm{~kg} / \mathrm{ha}$ dan urea $300 \mathrm{~kg} / \mathrm{ha}$ )
G. Pupuk NPK $300 \mathrm{~kg} / \mathrm{ha}+Z A 200 \mathrm{~kg} / \mathrm{ha}$
C. Pupuk NPK $300 \mathrm{~kg} / \mathrm{ha}+$ Urea $200 \mathrm{~kg} / \mathrm{ha}+\mathrm{ZA} 100 \mathrm{~kg} / \mathrm{ha}$
H. Pupuk NPK $300 \mathrm{~kg} / \mathrm{ha}+Z A 250 \mathrm{~kg} / \mathrm{ha}$
D. Pupuk NPK $300 \mathrm{~kg} / \mathrm{ha}+Z A 50 \mathrm{~kg} / \mathrm{ha}$
I. Pupuk NPK $300 \mathrm{~kg} / \mathrm{ha}+Z A 300 \mathrm{~kg} / \mathrm{ha}$
E. Pupuk NPK $300 \mathrm{~kg} / \mathrm{ha}+\mathrm{ZA} 100 \mathrm{~kg} / \mathrm{ha}$

\section{Pertumbuhan Tanaman}

Tinggi tanaman pada saat umur tanaman 35, 34 dan 55 hst menunjukan bahwa perlakuan takaran pemberian pupuk NPK+urea, NPK+ZA+urea, dan NPK+ZA menunjukan tidak berbeda nyata, namun tinggi tanaman tersebut berbeda nyata dengan perlakuan tanpa pupuk. Tinggi tanaman saat 55 hst dengan perlakuan takaran pmupukan kombinasi NPK+urea, NPK+ZA+urea, dan NPK+ZA berkisar 208.5 - 216.7 cm (Gambar 1). 


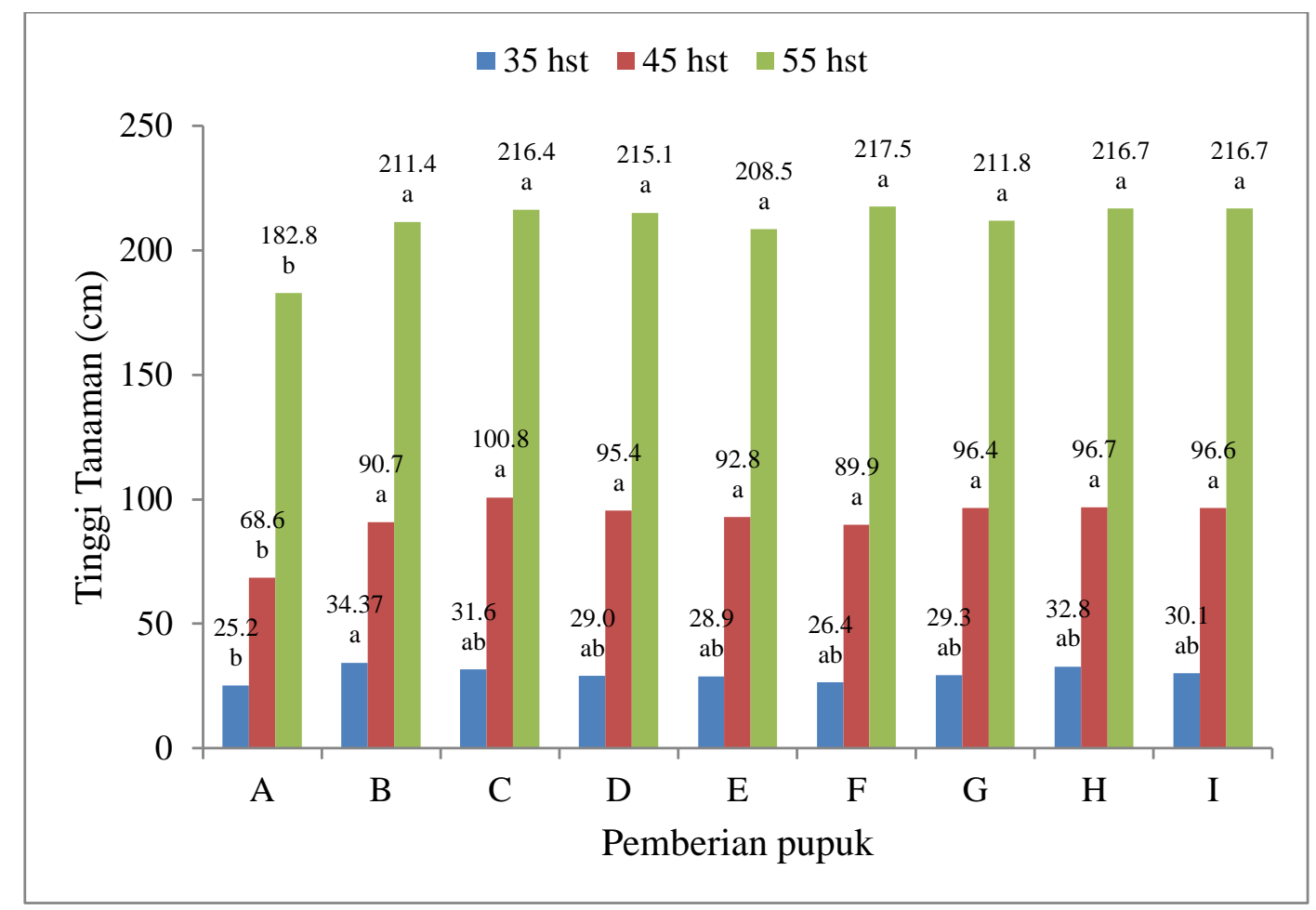

Keterangan:
A. Tanpa Pupuk
F. Pupuk NPK $300 \mathrm{~kg} / \mathrm{ha}+\mathrm{ZA} 150 \mathrm{~kg} / \mathrm{ha}$
B. Pupuk Rekomendasi (NPK $300 \mathrm{~kg} / \mathrm{ha}$ dan urea $300 \mathrm{~kg} / \mathrm{ha}$ )
G. Pupuk NPK $300 \mathrm{~kg} / \mathrm{ha}+\mathrm{ZA} 200 \mathrm{~kg} / \mathrm{ha}$
C. Pupuk NPK $300 \mathrm{~kg} / \mathrm{ha}+$ Urea $200 \mathrm{~kg} / \mathrm{ha}+$ ZA $100 \mathrm{~kg} / \mathrm{ha}$
H. Pupuk NPK $300 \mathrm{~kg} / \mathrm{ha}+Z A 250 \mathrm{~kg} / \mathrm{ha}$
D. Pupuk NPK $300 \mathrm{~kg} / \mathrm{ha}+\mathrm{ZA} 50 \mathrm{~kg} / \mathrm{ha}$
I. Pupuk NPK $300 \mathrm{~kg} / \mathrm{ha}+\mathrm{ZA} 300 \mathrm{~kg} / \mathrm{ha}$
E. Pupuk NPK $300 \mathrm{~kg} / \mathrm{ha}+\mathrm{ZA} 100 \mathrm{~kg} / \mathrm{ha}$

Chart 1. Tinggi tanaman pada saat tanaman berumur 35, 45, dan 55 hari setelah tanam Jumlah daun dan dimeter batang dengan pemberian pupuk NPK+urea, $\mathrm{NPK}+\mathrm{ZA}+$ urea, dan NPK+ZA pada saat 35 hst umunya tidak berbeda nyata pada perlakuan tanpa pemberian pupuk. Namun pada saat tanaman berumur 45 dan 55 hst menunjukkan bahwa jumlah daun dan diameter batang dengan pemberian pupuk NPK+urea, NPK+ZA+urea, dan NPK+ZA pada saat 35 hst berbeda nyata pada perlakuan tanpa pemberian pupuk. Kombinasi takaran pemberian pupuk NPK+urea, $\mathrm{NPK}+\mathrm{ZA}+$ urea, dan NPK+ZA (perlakuan $\mathrm{B}-1$ ) menunjukkan tidak beda nyata (Tabel 3). Menurut Lingga dan Marsono (2007), bahwa ketersediaan unsur nitrogen yang tinggi dapat meningkatkan pertumbuhan vegetatif tanaman. Hara $\mathrm{N}$ terlibat langsung dalam pembentukan asam amino, protein, asam nukleat, enzim, nucleoprotein, dan alkaloid, yang sangat dibutuhkan untuk proses pertumbuhan tanaman, terutama perkembangan daun, meningkatkan warna hijau daun yang berguna untuk proses fotosintesis( Nasreen et al. 2007, dan Abdissa et al. 2011). 
Tabel 3. Jumlah daun dan dimater batang pada beberapa perlakuan kombinasi takaran pemupukan NPK, urea dan ZA.

\begin{tabular}{|c|c|c|c|c|c|c|}
\hline $\begin{array}{c}\text { Pemberian } \\
\text { pupuk }\end{array}$ & $\begin{array}{c}\text { Jumlah } \\
\text { daun } \\
\text { saat } 35 \\
\text { hst }\end{array}$ & $\begin{array}{c}\text { Jumlah } \\
\text { daun saat } \\
45 \text { hst }\end{array}$ & $\begin{array}{c}\text { Jumlah } \\
\text { daun } \\
\text { saat } 55 \\
\text { hst }\end{array}$ & $\begin{array}{c}\text { Diamter } \\
\text { batang } \\
(\mathrm{mm}) \text { saat } \\
35 \text { hst }\end{array}$ & $\begin{array}{c}\text { Diamter } \\
\text { batang } \\
(\mathrm{mm}) \text { saat } \\
45 \text { hst }\end{array}$ & $\begin{array}{c}\text { Diamter } \\
\text { batang } \\
(\mathrm{mm}) \text { saat } \\
55 \text { hst }\end{array}$ \\
\hline A & $4.9 \mathrm{~b}$ & $6.2 \mathrm{a}$ & $12.3 \mathrm{a}$ & $19.2 \mathrm{~b}$ & $16.8 \mathrm{~b}$ & $17.6 \mathrm{~B}$ \\
\hline B & $5.8 \mathrm{ba}$ & $7.8 \mathrm{a}$ & $12.3 \mathrm{a}$ & $20.9 \mathrm{ba}$ & $22.7 \mathrm{a}$ & $23.1 \mathrm{~A}$ \\
\hline$C$ & $5.9 \mathrm{ba}$ & $8.2 \mathrm{a}$ & $13.9 \mathrm{a}$ & $22.7 \mathrm{a}$ & $22.2 \mathrm{a}$ & $22.6 \mathrm{~A}$ \\
\hline D & $5.6 \mathrm{ba}$ & $7.6 \mathrm{a}$ & $14.1 \mathrm{a}$ & $18.8 \mathrm{~b}$ & $21.5 \mathrm{a}$ & $20.8 \mathrm{~A}$ \\
\hline$E$ & $5.8 \mathrm{ba}$ & $7.6 \mathrm{a}$ & $14.2 \mathrm{a}$ & $19.9 \mathrm{ba}$ & $22.0 \mathrm{a}$ & $20.4 \mathrm{~A}$ \\
\hline $\mathrm{F}$ & $5.6 \mathrm{ba}$ & $8.2 \mathrm{a}$ & $14.3 \mathrm{a}$ & $21.5 \mathrm{ba}$ & $22.5 \mathrm{a}$ & $20.8 \mathrm{~A}$ \\
\hline G & $5.6 \mathrm{ba}$ & $8.1 \mathrm{a}$ & $14.5 \mathrm{a}$ & $20.8 \mathrm{ba}$ & $23.3 a$ & $22.1 \mathrm{~A}$ \\
\hline $\mathrm{H}$ & $5.7 \mathrm{ba}$ & $7.8 \mathrm{a}$ & $14.6 \mathrm{a}$ & $20.7 \mathrm{ba}$ & $21.9 \mathrm{a}$ & $21.6 \mathrm{~A}$ \\
\hline I & $5.9 a$ & $7.7 \mathrm{a}$ & $14.8 \mathrm{a}$ & $21.8 \mathrm{ba}$ & $21.8 \mathrm{~A}$ & $22.5 \mathrm{~A}$ \\
\hline KK & 9.1 & 7.7 & 9.7 & 7.7 & 7.2 & 7.0 \\
\hline
\end{tabular}

Keterangan:
A. Tanpa Pupuk
F. Pupuk NPK $300 \mathrm{~kg} / \mathrm{ha}+\mathrm{ZA} 150 \mathrm{~kg} / \mathrm{ha}$
B. Pupuk Rekomendasi (NPK $300 \mathrm{~kg} / \mathrm{ha}$ dan urea $300 \mathrm{~kg} / \mathrm{ha}$ )
G. Pupuk NPK $300 \mathrm{~kg} / \mathrm{ha}+\mathrm{ZA} 200 \mathrm{~kg} / \mathrm{ha}$
C. Pupuk NPK $300 \mathrm{~kg} / \mathrm{ha}+$ Urea $200 \mathrm{~kg} / \mathrm{ha}+$ ZA $100 \mathrm{~kg} / \mathrm{ha}$
H. Pupuk NPK $300 \mathrm{~kg} / \mathrm{ha}+Z A 250 \mathrm{~kg} / \mathrm{ha}$
D. Pupuk NPK $300 \mathrm{~kg} / \mathrm{ha}+\mathrm{ZA} 50 \mathrm{~kg} / \mathrm{ha}$
E. Pupuk NPK $300 \mathrm{~kg} / \mathrm{ha}+\mathrm{ZA} 100 \mathrm{~kg} / \mathrm{ha}$
I. Pupuk NPK $300 \mathrm{~kg} / \mathrm{ha}+\mathrm{ZA} 300 \mathrm{~kg} / \mathrm{ha}$

Panjang daun, lebar daun dan luas daun pada perlakuan pemberian pupuk $\mathrm{NPK}+$ urea, NPK+ZA+urea, dan NPK+ZA pada saat 35 hst umunya tidak berbeda nyata pada perlakuan tanpa pemberian pupuk. Namun pada saat tanaman berumur 45 dan 55 hst menunjukkan bahwa jumlah daun dan dimeter batang dengan pemberian pupuk NPK+urea, NPK+ZA+urea, dan NPK+ZA pada saat 35 hst berbeda nyata pada perlakuan tanpa pemberian pupuk. Kombinasi takaran pemberian pupuk $\mathrm{NPK}+$ urea, NPK+ZA+urea, dan NPK+ZA (perlakuan B - I) menunjukkan tidak beda nyata. Perlakuan kombinasi takaran pemupukan NPK, urea dan ZA menunjukkan bahwa tidak berbeda nyata antara perlakuan takaran pemberian pupuk NPK+urea, $\mathrm{NPK}+\mathrm{ZA}+$ urea, dan NPK+ZA (perlakuan B - Io). Namun demikian pemupukan Pupuk NPK $300 \mathrm{~kg} / \mathrm{ha}$ + Urea $200 \mathrm{~kg} / \mathrm{ha}+$ ZA $100 \mathrm{~kg} / \mathrm{ha}$ umumnya berpengaruh paling baik terhadap diameter tongkol, jumlah baris biji, jumlah biji/brais, rendemen biji, bobot biji (Tabel 4). 
Tabel 4. Komponen hasil dari perlakuan kombinasi pemupukan NPK, Urea dan ZA.

\begin{tabular}{lcccccc}
\hline $\begin{array}{c}\text { Pemberian } \\
\text { pupuk }\end{array}$ & $\begin{array}{c}\text { Diameter } \\
\text { tongkol } \\
(\mathrm{mm})\end{array}$ & $\begin{array}{c}\text { Jumlah } \\
\text { baris }\end{array}$ & $\begin{array}{c}\text { Jumlah } \\
\text { biji/baris }\end{array}$ & rendemen & $\begin{array}{c}\text { Bobot 100 } \\
\text { biji (g) }\end{array}$ & $\begin{array}{c}\text { Kadar air } \\
\text { biji panen } \\
(\%)\end{array}$ \\
\hline A & $30.5 \mathrm{~b}$ & $14.4 \mathrm{~b}$ & $18.6 \mathrm{~b}$ & $0.7 \mathrm{~b}$ & $3.6 \mathrm{C}$ & $32.4 \mathrm{tn}$ \\
$\mathrm{B}$ & $50.9 \mathrm{a}$ & $15.6 \mathrm{ba}$ & $35.2 \mathrm{a}$ & $0.8 \mathrm{a}$ & $4.5 \mathrm{Ba}$ & 32.3 \\
$\mathrm{C}$ & $51.0 \mathrm{a}$ & $16.0 \mathrm{a}$ & $35.7 \mathrm{a}$ & $0.8 \mathrm{a}$ & $4.7 \mathrm{~A}$ & 30.3 \\
$\mathrm{D}$ & $48.3 \mathrm{a}$ & $14.9 \mathrm{ba}$ & $33.8 \mathrm{a}$ & $0.8 \mathrm{a}$ & $4.2 \mathrm{Ba}$ & 31.2 \\
E & $48.9 \mathrm{a}$ & $14.8 \mathrm{ba}$ & $32.2 \mathrm{a}$ & $0.8 \mathrm{a}$ & $4.1 \mathrm{~B}$ & 32.3 \\
F & $49.8 \mathrm{a}$ & $15.2 \mathrm{ba}$ & $34.5 \mathrm{a}$ & $0.8 \mathrm{a}$ & $4.4 \mathrm{Ba}$ & 31.0 \\
$\mathrm{G}$ & $50.3 \mathrm{a}$ & $15.5 \mathrm{ba}$ & $36.0 \mathrm{a}$ & $0.8 \mathrm{a}$ & $4.5 \mathrm{~A}$ & 31.0 \\
$\mathrm{H}$ & $50.1 \mathrm{a}$ & $15.3 \mathrm{ba}$ & $34.3 \mathrm{a}$ & $0.8 \mathrm{a}$ & $4.2 \mathrm{Ba}$ & 32.2 \\
I & $50.5 \mathrm{a}$ & $15.6 \mathrm{ba}$ & $32.6 \mathrm{a}$ & $0.8 \mathrm{a}$ & $4.2 \mathrm{Ba}$ & 32.7 \\
\hline & 4.9 & 4.6 & 8.1 & 1.1 & 7.2 & 4.3 \\
\hline
\end{tabular}

Keterangan:
A. Tanpa Pupuk
F. PupukNPK $300 \mathrm{~kg} / \mathrm{ha}+Z A 150 \mathrm{~kg} / \mathrm{ha}$
B. Pupuk Rekomendasi (NPK $300 \mathrm{~kg} / \mathrm{ha}$ dan urea $300 \mathrm{~kg} / \mathrm{ha}$ )
G. Pupuk NPK $300 \mathrm{~kg} / \mathrm{ha}+Z A 200 \mathrm{~kg} / \mathrm{ha}$
C. Pupuk NPK $300 \mathrm{~kg} / \mathrm{ha}+$ Urea $200 \mathrm{~kg} / \mathrm{ha}+\mathrm{ZA} 100 \mathrm{~kg} / \mathrm{ha}$
H. Pupuk NPK $300 \mathrm{~kg} / \mathrm{ha}+\mathrm{ZA} 250 \mathrm{~kg} / \mathrm{ha}$
D. Pupuk NPK $300 \mathrm{~kg} / \mathrm{ha}+Z A 50 \mathrm{~kg} / \mathrm{ha}$
E. Pupuk NPK $300 \mathrm{~kg} / \mathrm{ha}+\mathrm{ZA} 100 \mathrm{~kg} / \mathrm{ha}$
I. Pupuk NPK $300 \mathrm{~kg} / \mathrm{ha}+Z A 300 \mathrm{~kg} / \mathrm{ha}$

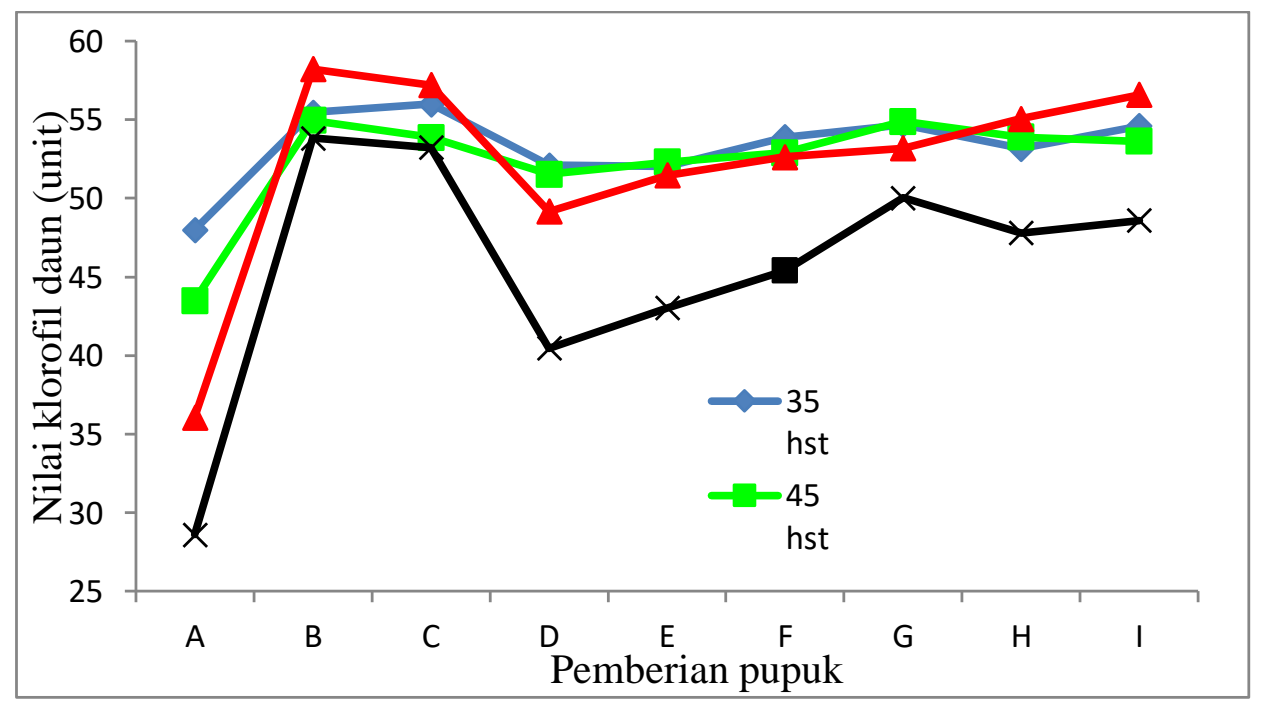

Keterangan:
A. Tanpa Pupuk
F. Pupuk NPK $300 \mathrm{~kg} / \mathrm{ha}+\mathrm{ZA} 150 \mathrm{~kg} / \mathrm{ha}$
B. Pupuk Rekomendasi (NPK $300 \mathrm{~kg} / \mathrm{ha}$ dan urea $300 \mathrm{~kg} / \mathrm{ha}$ )
G. Pupuk NPK $300 \mathrm{~kg} / \mathrm{ha}+\mathrm{ZA} 200 \mathrm{~kg} / \mathrm{ha}$
C. Pupuk NPK $300 \mathrm{~kg} / \mathrm{ha}+$ Urea $200 \mathrm{~kg} / \mathrm{ha}+$ ZA $100 \mathrm{~kg} / \mathrm{ha}$
H. Pupuk NPK $300 \mathrm{~kg} / \mathrm{ha}+Z A 250 \mathrm{~kg} / \mathrm{ha}$
D. Pupuk NPK $300 \mathrm{~kg} / \mathrm{ha}+\mathrm{ZA} 50 \mathrm{~kg} / \mathrm{ha}$
I. Pupuk NPK $300 \mathrm{~kg} / \mathrm{ha}+\mathrm{ZA} 300 \mathrm{~kg} / \mathrm{ha}$
E. Pupuk NPK $300 \mathrm{~kg} / \mathrm{ha}+Z A 100 \mathrm{~kg} / \mathrm{ha}$

Chart 2. Pengaruh kombinasi takaran pemberian pupuk NPK, urea, dan ZA terhadap Klorofil daun pada saat tanaman berumur $35,45,55$, dan 85 hst 
Berdasarkan analisis statistik pembentukan zat hijau daun atau klorfil daun dengan pemberian ZA pada perlakuan pemupukan $\mathrm{B}-\mathrm{H}$ pada saat 35 tidak berbeda nyata yaitu berkisar 52.0 - 56 unit, namun pada saat umur 45 kandungan klorofil pada perlakuan pemupukan perlakuan D (NPK $300 \mathrm{~kg} / \mathrm{ha}+$ ZA $50 \mathrm{~kg} / \mathrm{ha}$ ) dan E (Pupuk NPK $300 \mathrm{~kg} / \mathrm{ha}+$ ZA $1000 \mathrm{~kg} / \mathrm{ha}$ ) nyata lebih rendah yaitu hanya 51.5 - 52.3 unit dibanding perlakuan pemupukan B, C, E - I dengan nilai klorofil sebesar 52.9 53.9 unit. Pada saat fase berbunga ( $5 \mathrm{hst}$ ) dan fase $\mathrm{R}_{5}$ ( $85 \mathrm{hst}$ ) perlakuan pemupukan $D$ dan $E$ lebih rendah dibanding perlakuan $B, C$ dan $F, G, H, I$ (Gambar 2).

\section{Kandungan N, P, K, dan S dalam Jaringan}

Kandungan hara dalam jaringan daun pada saat fase pembungaan ( 55 hst) menunjukkan bahwa kandungan $\mathrm{N}$ pada tanaman yang tidak diberi pupuk dapat menyerap hara N P K S dalam tanah. Kandungan N P K S dalam jaringan daun masing-masing sebesar 1,83; 0,29; 1,24; dan $0.08 \mathrm{~g} / 100 \mathrm{~g}$. Berdasarkan nilai batas kritis kecukupan hara menurut Fathan et al. (1988) bahwa kandungan N, P barada pada batas yang cukup namun kandungan hara $\mathrm{K}$ dan $\mathrm{S}$ dibawah batas krtitis kecukupan hara. Hal tersebut menunjukkan bahwa lahan percobaan mempunyai kandungan $\mathrm{N}$ dan $\mathrm{P}$ yang cukup untuk pertumbuhan tanaman jagung namun perlu penambahan pupuk $\mathrm{K}$ dan $\mathrm{S}$. Sulfur yang diberikan dalam bentuk ZA dalam tanaman dapat mengurangi pelepasan gas metana dan dinitrogen oksida ke atmosfer ( Blair et al .,1993)

Tabel 5. Kandungan N, P, K, dan S dalam jaringan daun pada saat tanaman berumur 55 hst

\begin{tabular}{|c|c|c|c|c|c|c|c|c|}
\hline \multirow{3}{*}{$\frac{\text { Perlakaun }}{\mathrm{A}}$} & \multicolumn{8}{|c|}{ Kandungan hara jaraingan daun (g/10og) } \\
\hline & \multicolumn{2}{|c|}{$\mathrm{N}$} & \multicolumn{2}{|c|}{$\mathrm{P}$} & \multicolumn{2}{|c|}{$\mathrm{K}$} & \multicolumn{2}{|c|}{$\mathrm{S}$} \\
\hline & 1.83 & $d$ & 0.29 & C & 1.24 & $\mathrm{~b}$ & 0.08 & $\mathrm{C}$ \\
\hline B & 3.07 & $a$ & 0.35 & ba & 2.16 & ba & 0.11 & $\mathrm{Bc}$ \\
\hline C & 2.94 & ba & 0.37 & $\mathrm{a}$ & 2.28 & a & 0.12 & Bac \\
\hline D & 2.21 & dc & 0.33 & $\mathrm{~b}$ & 1.57 & ba & 0.09 & C \\
\hline$E$ & 2.40 & bdc & 0.32 & bc & 1.66 & ba & 0.11 & $\mathrm{Bac}$ \\
\hline $\mathrm{F}$ & 2.66 & ba & 0.33 & $b$ & 1.87 & ba & 0.15 & A \\
\hline$G$ & 2.90 & bac & 0.33 & $b$ & 2.27 & $a$ & 0.14 & $\mathrm{Ba}$ \\
\hline $\mathrm{H}$ & 2.83 & ba & 0.32 & bc & 2.35 & $a$ & 0.14 & $\mathrm{Ba}$ \\
\hline 1 & 2.77 & bac & 0.33 & $b$ & 2.30 & $a$ & 0.12 & $\mathrm{Bac}$ \\
\hline
\end{tabular}

Keterangan:
A. Tanpa Pupuk
F. Pupuk NPK $300 \mathrm{~kg} / \mathrm{ha}+\mathrm{ZA} 150 \mathrm{~kg} / \mathrm{ha}$
B. Pupuk Rekomendasi (NPK $300 \mathrm{~kg} / \mathrm{ha}$ dan urea $300 \mathrm{~kg} / \mathrm{ha}$ )
G. Pupuk NPK $300 \mathrm{~kg} / \mathrm{ha}+\mathrm{ZA} 200 \mathrm{~kg} / \mathrm{ha}$
C. Pupuk NPK $300 \mathrm{~kg} / \mathrm{ha}+$ Urea $200 \mathrm{~kg} / \mathrm{ha}+$ ZA $100 \mathrm{~kg} / \mathrm{ha}$
H. Pupuk NPK $300 \mathrm{~kg} / \mathrm{ha}+Z A 250 \mathrm{~kg} / \mathrm{ha}$
D. Pupuk NPK $300 \mathrm{~kg} / \mathrm{ha}+\mathrm{ZA} 50 \mathrm{~kg} / \mathrm{ha}$
E. Pupuk NPK $300 \mathrm{~kg} / \mathrm{ha}+\mathrm{ZA} 100 \mathrm{~kg} / \mathrm{ha}$
I. Pupuk NPK $300 \mathrm{~kg} / \mathrm{ha}+\mathrm{ZA} 300 \mathrm{~kg} / \mathrm{ha}$ 
Pupuk ZA mengandung belerang 24\% (dalam bentuk sulfat) dan nitrogen $21 \%$ (dalam bentuk amonium). Kandungan nitrogennya hanya separuh dari urea, sehingga biasanya pemberiannya dimaksudkan sebagai sumber pemasok hara belerang pada tanah-tanah yang miskin unsur ini. Unsur $\mathrm{S}$ dalam tanaman merupakan salah satu unsur makro yang banyak dibutuhkan tanaman karena unsur $S$ merupakan salah satu unsur utama penyusun inti sel dan unsur penting dalam pembentukan protein (Miller and Donahue, 1990). Pemberian pupuk ZA meningkatkan kandungan $\mathrm{N}$ dan $\mathrm{S}$ dalam jaringan tanaman. Bilamana hara $\mathrm{S}$ terbatas, penambahan pupuk nitrogen tidak mengubah hasil dan kandungan protein dalam tanaman (Singh et al ., 2010).

Pada Gambar 3 menunjukkan bahwa pemberian pupuk ZA dapat meningkatkan serapan pupuk $\mathrm{K}$. hal ini menunjukkan adanya hubungan nyata kecukupan hara $\mathrm{S}$ dengan kemampuan tanaman menyerap $\mathrm{K}$ dari dalam tanah dengan nilai koefesien korelasi $\left(\mathrm{R}^{2}\right)$ sebesar 0,95. Unsur $\mathrm{K}$ berfungsi sebagai media transportasi yang membawa hara-hara dari akar dan mentranslokasi asimilat dari daun keseluruh jaringan tanaman. Kurangnya hara $\mathrm{K}$ dalam tanaman dapat menghambat proses transportasi dalam tanaman (F.J.Stevenson, 1994). Oleh karena itu, agar proses transportasi unsur hara maupun asimilat dalam tanaman dapat berlangsung optimal maka unsur hara $\mathrm{K}$ dalam tanaman harus optimal. Serapan hara $\mathrm{K}$ dari tanah oleh tanaman dapat berlangsung optimal bila tersedia energi ATP yang cukup yang membutuhkan memerlukan banyak energi dari ATP yang diperoleh dari P (Fitter dan Hay, 1991) dan P yang tersedia dalam tanah tergolong tinggi (Tabel 5).

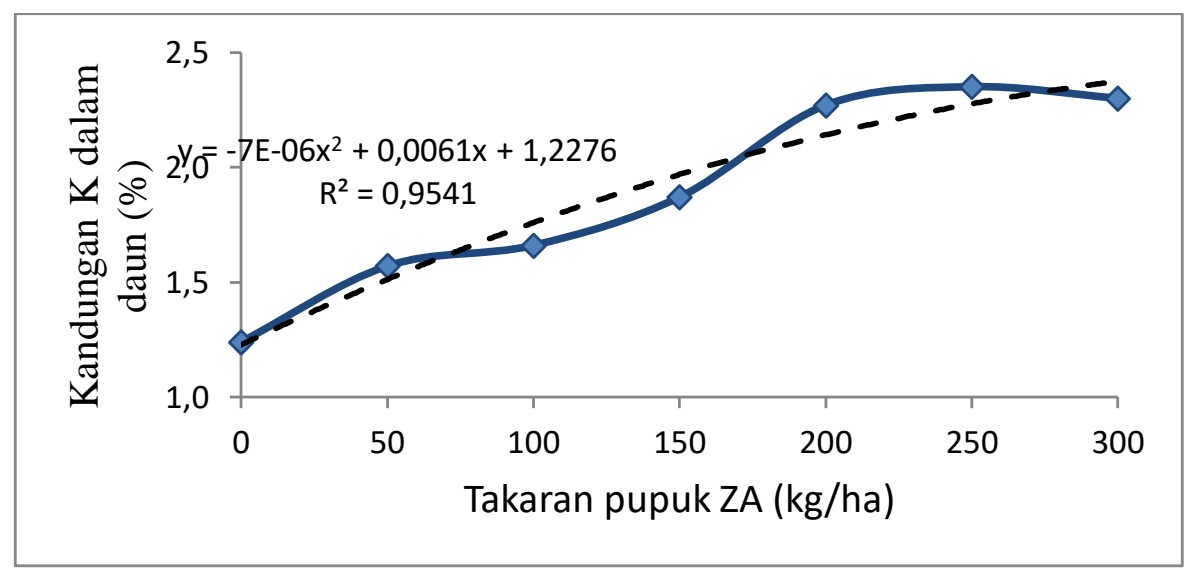

Chart 3. Hubungan takaran pemberian pupuk ZA dengan kandungan K dalam jaringan daun

Di dalam tanaman antara unsur $\mathrm{P}$ dan $\mathrm{K}$ ada saling ketergantungan. Unsur $\mathrm{K}$ berfungsi sebagai media transportasi yang membawa hara-hara dari akar termasuk hara $\mathrm{P}$ ke daun dan mentranslokasi asimilat dari daun keseluruh jaringan tanaman, 
juga berperan dalam pembentukan pati, mengaktifkan enzim, pembukaan stomata, proses fisiologis dalam tanaman, proses metabolik dalam sel, mempengaruhi penyerapan unsur-unsur lain, mempertinggi daya tahan terhadap kekeringan, penyakit selain itu juga berperan dalam perkembangan akar (Agustina, 1990), kurangnya hara $\mathrm{K}$ dalam tanaman dapat menghambat proses transportasi dalam tanaman. Oleh karena itu, agar proses transportasi unsur hara maupun asimilat dalam tanaman dapat berlangsung optimal maka unsur hara $\mathrm{K}$ dalam tanaman harus optimal. Serapan hara $\mathrm{K}$ termasuk hara $\mathrm{P}$ dari tanah oleh tanaman dapat berlangsung optimal bila tersedia energi ATP yang cukup karena hara $\mathrm{K}$ dan $\mathrm{P}$ diserap tanaman melalui proses "difusi" yang memerlukan banyak energi dari ATP (Fitter dan Hay, 1991). Tanaman akan dapat membentuk ATP secara optimal bila serapan hara $\mathrm{P}$ juga optimal. Berdasarkan hasil analisis jaringan menunjukkan bahwa serapan $\mathrm{P}$ tergolong cukup hal tersebut disebabkan ketersedian $\mathrm{P}$ dalam tanah tercukupi karena diberikan pupuk NPK dengan takaran $300 \mathrm{~kg} / \mathrm{ha}$.

\section{Indeks Panen}

Indeks panen merupakan ratio bobot biji dengan bobot biomas. Semakin tinggi indeks panen tanaman jagung menunjukan bahwa partisi fotosintat di tajuk banyak ditrans lokasi ke bagian biji. Indeks panen pada perlakuan tanpa pupuk nyata lebih rendah yaitu 0.26 dibanding dengan perlakuan pemupukan B - I, namun indeks panen antar perlakuan pemupukan ( $\mathrm{B}-\mathrm{I}$ ) tidak nyata. Nilai indeks panen diperoleh dari perlekuan pemupukan antara 0,39-0,42. Nilai indeks panen tertingi diperoleh dari perlakuakan pemupukan NPK $300 \mathrm{~kg} / \mathrm{ha}+$ Urea $200 \mathrm{~kg} / \mathrm{ha}+$ ZA 100 $\mathrm{kg} / \mathrm{ha}$ sebesar 0,42 .

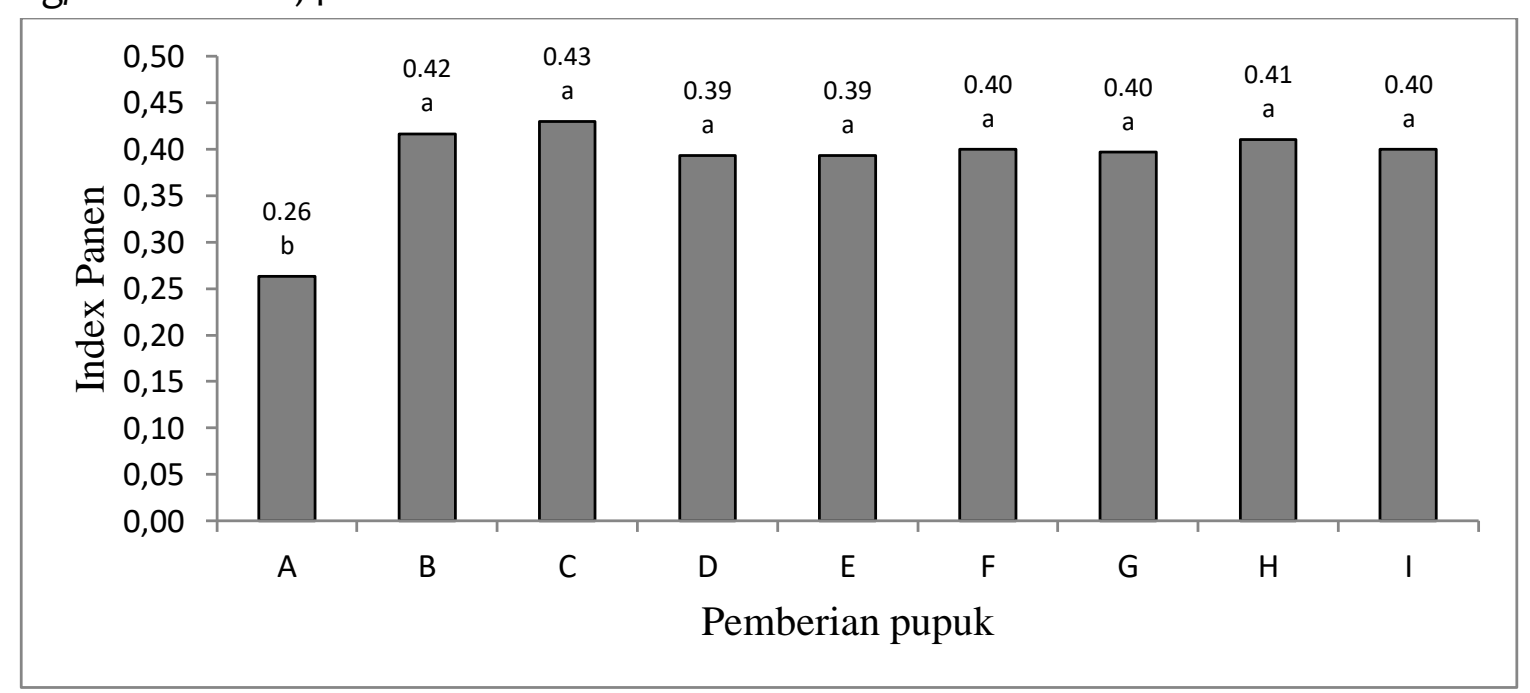

\section{Keterangan:}
A. Tanpa Pupuk
B. Pupuk Rekomendasi (NPK $300 \mathrm{~kg} / \mathrm{ha}$ dan urea $300 \mathrm{~kg} / \mathrm{ha})$
C. Pupuk NPK $300 \mathrm{~kg} / \mathrm{ha}+$ Urea $200 \mathrm{~kg} / \mathrm{ha}+\mathrm{ZA} 100 \mathrm{~kg} / \mathrm{ha}$
D. Pupuk NPK $300 \mathrm{~kg} / \mathrm{ha}+\mathrm{ZA} 50 \mathrm{~kg} / \mathrm{ha}$
E. Pupuk NPK $300 \mathrm{~kg} / \mathrm{ha}+\mathrm{ZA} 100 \mathrm{~kg} / \mathrm{ha}$

F. Pupuk NPK $300 \mathrm{~kg} / \mathrm{ha}+$ ZA $150 \mathrm{~kg} / \mathrm{ha}$

G. Pupuk NPK $300 \mathrm{~kg} / \mathrm{ha}+$ ZA $200 \mathrm{~kg} / \mathrm{ha}$

H. Pupuk NPK $300 \mathrm{~kg} / \mathrm{ha}+\mathrm{ZA} 250 \mathrm{~kg} / \mathrm{ha}$

I. Pupuk NPK $300 \mathrm{~kg} / \mathrm{ha}+$ ZA $300 \mathrm{~kg} / \mathrm{ha}$ 
Produksi biji pada perlakuan pemupukan B - I menunjukan hasil yang tidak berbeda nyata yaitu berkisar 8,9 - 10, $8 \mathrm{t} / \mathrm{ha}$, namun produksi tertinggi terdapat pada perlakuan pemupukan NPK $300 \mathrm{~kg} / \mathrm{ha}$ dan urea $300 \mathrm{~kg} / \mathrm{ha}$ dan $300 \mathrm{~kg} / \mathrm{ha}+$ Urea $200 \mathrm{~kg} / \mathrm{ha}+$ ZA $100 \mathrm{~kg} / \mathrm{ha}$ yaitu berkisar 10,8 t/ha. Pada pemberian NPK $300 \mathrm{~kg}$ + Za 50 - $200 \mathrm{~kg}$ menunjukkan hasil yang meningkat dari hasil 8,9 t/ha menjadi 9,9 $\mathrm{t} /$ ha, peningkatan hasil tersebut disebabkan karena peningkatan jumlah hara $\mathrm{S}$ dan $\mathrm{K}$ yang semakin meningkat, namun bila takaran pemberian pupuk ZA ditingkatkan menjadi 250 - $300 \mathrm{~kg}$ justru menunjukkan penurunan produksi menjadi 9,8 t/ha - 9,4 t/ha (chart 5).

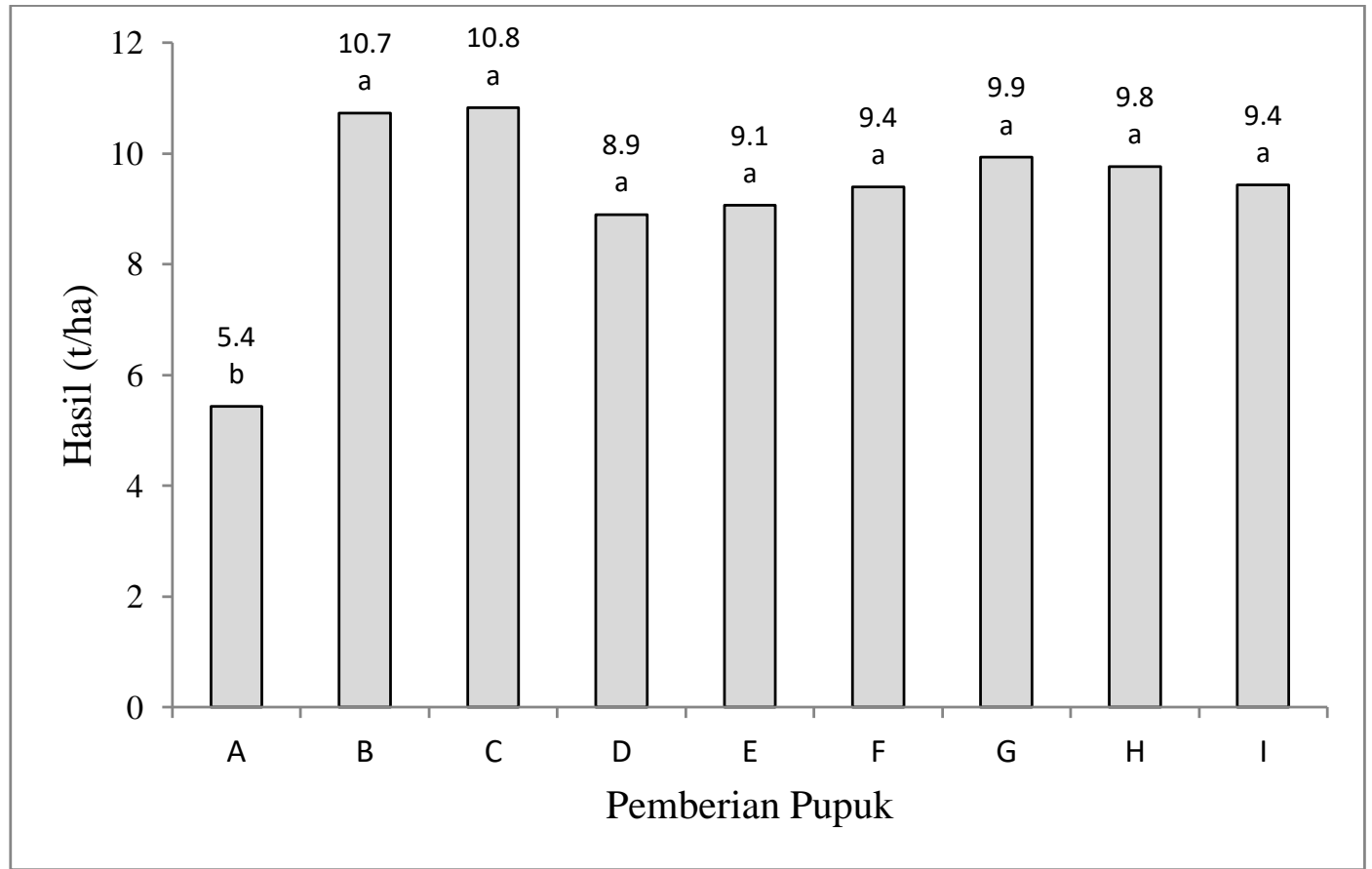

Keterangan:

Koefesien keragaman $=12,8 \%$
A. Tanpa Pupuk
B. Pupuk Rekomendasi (NPK $300 \mathrm{~kg} / \mathrm{ha}$ dan urea $300 \mathrm{~kg} / \mathrm{ha}$ )
F. Pupuk NPK $300 \mathrm{~kg} / \mathrm{ha}+\mathrm{ZA} 150 \mathrm{~kg} / \mathrm{ha}$
C. Pupuk NPK $300 \mathrm{~kg} / \mathrm{ha}+$ Urea $200 \mathrm{~kg} / \mathrm{ha}+\mathrm{ZA} 100 \mathrm{~kg} / \mathrm{ha}$
G. Pupuk NPK $300 \mathrm{~kg} / \mathrm{ha}+Z A 200 \mathrm{~kg} / \mathrm{ha}$
H. Pupuk NPK $300 \mathrm{~kg} / \mathrm{ha}+Z A 250 \mathrm{~kg} / \mathrm{ha}$
D. Pupuk NPK $300 \mathrm{~kg} / \mathrm{ha}+$ ZA $50 \mathrm{~kg} / \mathrm{ha}$
I. Pupuk NPK $300 \mathrm{~kg} / \mathrm{ha}+$ ZA $300 \mathrm{~kg} / \mathrm{ha}$

Chart 5. Pengaruh kombinasi pemeberian pupuk NPK, urea, dan ZA terhadap produksi

\section{Analisis Usahatani}

Untuk mendapatkan informasi tentang pengaruh perlakuan yang diberikan terhadap tingkat pendapatan yang diperoleh maka dilakukan analisis usahatani. Rangkuman hasil analisis usahatani disajikan pada Tabel 6. 
Tabel 6. Analisis Usaha Tani

\begin{tabular}{|c|c|c|c|c|c|c|c|}
\hline $\begin{array}{c}\text { N } \\
\mathbf{o}\end{array}$ & $\begin{array}{c}\text { Perlak } \\
\text { uan }\end{array}$ & $\begin{array}{c}\text { Hasil } \\
\text { (ton/ha) }\end{array}$ & $\begin{array}{c}\text { Total Biaya } \\
(\mathbf{R p})\end{array}$ & $\begin{array}{c}\text { Biaya/kg } \\
\text { (Rp) }\end{array}$ & $\begin{array}{c}\text { Pendapatan } \\
(\mathbf{R p})\end{array}$ & $\begin{array}{c}\text { Keuntungan } \\
(\mathbf{R p})\end{array}$ & $\begin{array}{c}\text { B/C } \\
\text { Rasio }\end{array}$ \\
\hline 1 & A & 5,4 & $\mathbf{6 , 8 8 5 , 0 0 0}$ & 1,275 & $16,200,000$ & $9,315,000$ & 1.35 \\
\hline 2 & B & 10,7 & $\mathbf{9 , 6 6 0 , 0 0 0}$ & 903 & $32,100,000$ & $22,440,000$ & 2.32 \\
\hline 3 & C & 10,8 & $\mathbf{9 , 6 9 5 , 0 0 0}$ & 898 & $32,400,000$ & $22,705,000$ & 2.34 \\
\hline 4 & D & 8,9 & $\mathbf{8 , 7 1 0 , 0 0 0}$ & 979 & $26,700,000$ & $17,990,000$ & 2.07 \\
\hline 5 & E & 9,1 & $\mathbf{8 , 8 5 5 , 0 0 0}$ & 973 & $27,300,000$ & $18,445,000$ & 2.08 \\
\hline 6 & F & 9,4 & $\mathbf{9 , 0 3 0 , 0 0 0}$ & 961 & $28,200,000$ & $19,170,000$ & 2.12 \\
\hline 7 & G & 9,9 & $\mathbf{9 , 2 6 5 , 0 0 0}$ & 936 & $29,700,000$ & $20,435,000$ & 2.21 \\
\hline 8 & H & 9,8 & $\mathbf{9 , 3 2 0 , 0 0 0}$ & 951 & $29,400,000$ & $20,080,000$ & 2.15 \\
\hline 9 & I & 9,4 & $\mathbf{9 , 2 8 5 , 0 0 0}$ & 988 & $28,200,000$ & $18,915,000$ & 2.04 \\
\hline
\end{tabular}

Pemberian Pupuk sesuai rekomendasi (NPK 300 + Urea $300 \mathrm{~kg} / \mathrm{ha}$ ) dengan biaya produksi Rp. 903 / kg, menghasilkan keuntungan Rp. 22.440.000,- dan B/C Rasio 2,32, dan apabila pupuk Urea nya di dikurangi menjadi $200 \mathrm{~kg} / \mathrm{ha}$ dan ditambahkan pupuk ZA $100 \mathrm{~kg} / \mathrm{ha}$, maka akan mengurangi biaya produksi menjadi Rp. $898 / \mathrm{kg}$, terjadi peningkatan keuntungan menjadi Rp. 22.705.000,- dengan B-C Rasio 2,34. Perlakuan tanpa urea, pada perlakuan dosis pupuk NPK 300/kg + ZA 100 $\mathrm{kg} / \mathrm{ha}$ akan menurunkan hasil produksi dari 10,8 ton/ha menjadi 9,1 ton/ha, dan B-C Rasio 2,34 menjadi 2,08. Selanjutnya perlakuan tanpa urea (NPK + Urea) mempunyai produksi tertinggi pada pemberian pupuk NPK $300 \mathrm{~kg} / \mathrm{ha}+\mathrm{ZA} 200$ kg/ha dengan tingkat keuntungan Rp. 20.435.000,- dan B-C Rasio 2,21. Selanjutnya penambahan takaran pupuk ZA malah akan menurunkan hasil produksi serta B-C Rasionya.

\section{KESIMPULAN}

Berdasarkan hasil penelitian yang diperoleh, maka terdapat beberapa kesimpulan yang dapat dirumuskan, diantaranya adalah sebagai berikut:

1. Pemberian pupuk NPK $300 \mathrm{~kg} / \mathrm{ha}+$ urea $300 \mathrm{~kg} / \mathrm{ha}$ atau NPK $300 \mathrm{~kg} / \mathrm{ha}+$ Urea $200 \mathrm{~kg} / \mathrm{ha}+\mathrm{ZA} 100 \mathrm{~kg} / \mathrm{ha}$ berpengaruh paling baik terhadap pertumbuhan dengan indeks panen 0,43 dan hasil berkisar 10,8 t/ha.

2. Perlakuan penambahan pupuk ZA sebesar $50-300 \mathrm{~kg} / \mathrm{ha}$ yang dikombinasikan dengan pemupukan NPK dapat meningkatkan penyerapan hara Kalium (K)

3. Perlakuan penambahan pupuk ZA sebesar $50-300 \mathrm{~kg} / \mathrm{ha}$ yang dikombinasikan dengan pemupukan NPK menunjukkan takaran optimal pemupukan adalah NPK $300 \mathrm{~kg} / \mathrm{ha}+$ ZA $200 \mathrm{~kg} / \mathrm{ha}$ dengan hasil produksi 9,9 t/ha. Tingkat keuntungan yang diperoleh adalah Rp. 20.435.000,- dengan B-C Rasio 2,21.

4. Pemberian Pupuk sesuai rekomendasi (NPK $300+$ Urea $300 \mathrm{~kg} / \mathrm{ha}$ ) menghasilkan keuntungan Rp. 22.440.000,- dan B/C Rasio 2,32. Selanjutnya, apabila dosis Urea 
dikurangi menjadi $200 \mathrm{~kg} / \mathrm{ha}+\mathrm{ZA} 100 \mathrm{~kg} / \mathrm{ha}$, akan menurunkan biaya produksi dan meningkatkan keuntungan menjadi Rp. 22.705.000,- dengan B-C Rasio 2,34.

5. Perlakuan penambahan pupuk ZA sebesar $50-300 \mathrm{~kg} / \mathrm{ha}$ yang dikombinasikan dengan pemupukan NPK menunjukkan takaran optimal pemupukan adalah NPK $300 \mathrm{~kg} / \mathrm{ha}+$ ZA $200 \mathrm{~kg} / \mathrm{ha}$ dengan hasil produksi 9,9 t/ha. Tingkat keuntungan yang diperoleh adalah Rp. 20.435.000,- dengan B-C Rasio 2,21.

\section{DAFTAR PUSTAKA}

Agustina, L. 1990. Dasar Nutrisi Tanaman. Rineka Cipta. Jakarta.

Blair, G.J., R.D.B. Lefroy, N. Chinoim, and G.C. Anderson. 1993. Sulfur soil testing. Plant Soil 156: 383-386.

BPS, 2015. Data Produksi Pertanian. www.bps.go.id

Dobermann, A. and T. Fairhurst. 2000. Rice: Nutrient disorders \& nutrient management. PPI - PPIC - IRRI.

Fathan, R. M. Raharjo, A.K. Makarim. 1988. Hara tanaman jagung. Dalam: Jagung. Subandi et al. (Eds.). Puslitbangtan. Bogor. p. 49-66.

FAO. 2012. Maize Balance Sheet. http//sulfur.fao.org/site/616/DesktopDefaul.t,aspx

Feaglay and Hossner, 1978. Nitrogen in Agricultural Soils, American Society of Agronomy.

Fitter A.H. dan R.K.H. Hay. 1991. Fisiologi Lingkungan Tanaman. Gajahmada University Press. Yogyakarata. 416h.

F.J.Stevenson. 1994. Humus,Chemistry,Genesis,Composition, Reaction. Departement of Agronomy University of Illions.

Ispandi A. dan Munip A. 2004. Efektivitas pupuk P K dan frekuensi pemberian pupuk $\mathrm{K}$ dalam meningkatkan serapan hara dan produksi kacang tanah di lahan kering alfisol Ilmu Pertanian Vol. 11 No. 2, 2004 : 11-24

Jones,J.B.,Wolf,J.B. and Mills, F.L.A. 1991. Plant Analysis Handbook. Micro-Macro Pub. Inc.,USA.213p

Lingga, P dan Marsono. 2007. Petunjuk Penggunaan Pupuk. Edisi Revisi.: Penebar Swadaya Jakarta.

Mengel, K. and E.A. Kirby. 1987. Principles of plant nutrition. 4th Edition. International Potash Institute, Bern, Switzerland.

Miller R.W. and R.L.Donahue. 1990. An Introduction to Soil and Plant Growth. Prentice Hall International Edition. Englewood, New Yersey. 769p.

Nasreen, S, Haque, MM, Hosain, MA \& Farid, ATM 2007, 'Nutrient uptake and yield of onion as influenced by nitrogen and sulphur fertilization, Bangladesh', J. Agril. Res., vol. 32, no. 3, pp. 413-20

N.K.Fageria. 2016. The use of Nutrients in Crop Plants. CRC Press, Taylor \& Francis Group. Boca raton. London New York. 448p 
Nasreen, S, Haque, MM, Hosain, MA \& Farid, ATM 2007, 'Nutrient uptake and yield of onion as influenced by nitrogen and sulphur fertilization, Bangladesh', J. Agril. Res., vol. 32, no. 3, pp. 413-20.

Singh, A.K., Manibhushan, M.K. Meena, and A. Upadhyaya. 2012. Effect of Sulphur and Zinc on Rice Performance and Nutrient Dynamics in Plants and Soil of Indo Gangetic Plains. Journal of Agricultural Science 4(11): 162-170.

Swandi,D.1999.Pengaruh Langsung Pupuk Nitrogen Pelepas Lambat padaTanaman Kentang. J.Ho rt. 4(2):29. 